\title{
Markers for Characterization of Bone Marrow Multipotential Stromal Cells
}

\author{
Sally A. Boxall and Elena Jones \\ Academic Unit of the Musculoskeletal Diseases, St. James's University Hospital, Leeds Institute of Molecular Medicine, \\ University of Leeds, Leeds LS9 7TF, UK \\ Correspondence should be addressed to Elena Jones, e.jones@leeds.ac.uk
}

Received 26 January 2012; Accepted 29 February 2012

Academic Editor: Selim Kuçi

Copyright ( $\odot 2012$ S. A. Boxall and E. Jones. This is an open access article distributed under the Creative Commons Attribution License, which permits unrestricted use, distribution, and reproduction in any medium, provided the original work is properly cited.

\begin{abstract}
Given the observed efficacy of culture-expanded multipotential stromal cells, also termed mesenchymal stem cells (MSCs), in the treatment of graft-versus host and cardiac disease, it remains surprising that purity and potency characterization of manufactured cell batches remains rather basic. In this paper, we will initially discuss surface and molecular markers that were proposed to serve as the indicators of the MSC potency, in terms of their proliferative potential or the ability to differentiate into desired lineages. The second part of this paper will be dedicated to a critical discussion of surface markers of uncultured (i.e., native) bone marrow (BM) MSCs. Although no formal consensus has yet been reached on which markers may be best suited for prospective BM MSC isolation, markers that cross-react with MSCs of animal models (such as CD271 and W8-B2/MSCA-1) may have the strongest translational value. Whereas small animal models are needed to discover the in vivo function on these markers, large animal models are required for safety and efficacy testing of isolated MSCs, particularly in the field of bone and cartilage tissue engineering.
\end{abstract}

\section{Introduction}

BM MSCs were discovered in the late 1970s by a group led by a Russian-born scientist Alexander Friedenstein, who showed that BM contains a population of plasticadherent, highly proliferative cells, that were able to form colony of fibroblasts (hence the name colony-forming unit-fibroblasts, CFU-F) $[1,2]$. Following implantation in diffusion chambers, CFU-Fs spontaneously formed bone, cartilage, and fibrous tissue in vivo [3]. Whereas Friedenstein termed them "determined osteogenic progenitors" [4], the subsequent findings of their multipotentiality toward other mesenchymal lineages led Arnold Caplan to coin the term "mesenchymal stem cells" [5], in analogy to "hematopoietic stem cells" (HSC), which were the best described adult stem cell type at the time.

\section{Potency Markers of Cultured MSCs}

The first definitive markers of MSCs were proposed in a pioneering study of Pittenger et al., the group who also developed robust and reproducible in vitro assays of MSC multipotentiality towards bone, cartilage, and fat lineages [6]. These BM MSC markers included $\mathrm{SH} 2$ and $\mathrm{SH} 3$, later shown to correspond to CD105 and CD73 molecules, respectively $[7,8]$. Of note, $\mathrm{CD}$ stands for "cluster of differentiation", the standard nomenclature for cell surface molecules. These two markers alongside CD90 are positively expressed on MSCs and remain the primary molecules used to identify MSCs by the International Society of Cell Therapy (ISCT) position statement [9]. The ISCT position statement also advices that MSCs should be negative for the expression of CD11b or CD14, CD19 or CD79a, CD34, CD45, and HLA-DR [9]. This is primarily to allow the exclusion of haematopoetic cells which may contaminate MSC cultures.

CD105, also known as endoglin, is the TGF-beta receptor III, which potentially plays a role in TGF-beta signalling during MSC chondrogenic differentiation [7]. CD73 is an ecto-5'-nucleotidase, which is known to be involved in BM stromal interactions [8], MSC migration [10], and, potentially, MSC modulation of adaptive immunity [11]. The exact function of the CD90 (Thy1 antigen) is less well 
defined. It has been proposed to mediate cell-cell interactions $[12,13]$, involved in adhesion of monocytes and leukocytes to endothelial cells and fibroblasts $[14,15]$, and may have a role in the stromal adherence of CD34+ cells [16].

Cultured MSCs are uniformly and strongly positive for CD105, CD90, and CD73, regardless of their passage or time in culture $[6,17]$. However, CD105 and CD73 are also expressed on skin fibroblasts $[18,19]$, cells with a much lower ability to proliferate and differentiate, compared to BM MSCs [6, 19]. Furthermore, another plastic-adherent cell type that is able to propagate in vitro-umbilical vein endothelial cells-is also CD105 and CD73 positive $[20,21]$. This implies that sole demonstration of CD105 and CD73 expression without CD90 on adherent cultured cells is insufficient to prove their MSC identity. Another disadvantage of CD73 and CD105 is a limited cross-reactivity of anti-human antibodies with animal cells (Table 1), an issue that will be discussed later in the paper.

A complication regarding the long-term cultivation of MSCs was raised when Prockop's group showed a reduction in their colony-forming efficiency with increasing passage [22]. Earlier passage MSCs were documented to have better colony-forming efficiency compared to later passages [22]. This phenomenon was shown to be linked with telomere erosion [23] and later described as "in vitro MSC ageing" [24]. These ideas were further extended by Wagner et al. who showed that alterations in phenotype, differentiation potential, gene expression, and miRNA patterns "are not restricted to later passages, but are continuously acquired with increasing passage" from the first passage onwards [25]. The fact that CD105, CD73, and CD90 are expressed at similar levels in early-passage (potent) and late-passage (aged, presenescent) MSCs indicates that their value maybe limited only to basic MSC characterization. The limitation of these markers is further demonstrated by the fact that although CD73 and CD105 are expressed on clonally derived MSCs [6], only $1 / 3$ of these clones are truly multipotential [6]. This suggests that CD73 and CD105 expression may not be directly linked with MSC differentiation capacity.

Stro-1 was another molecule described to be highly specific for BM CFU-F [26]. However, the Stro-1 antigen remains unclustered, limiting its widespread use in human and animal experimentation. Interestingly, Stro-1 expression is downregulated during prolonged culture [26]. The function of Stro-1 on MSCs remains largely unknown; in one study, Stro- $1^{+}$-expanded MSCs were reported to have a better homing capacity, compared to expanded Stro- $1^{-}$ MSCs, suggesting its potential role in MSC migration and attachment to extracellular matrix [27]. In 2003, Gronthos et al. refined their CFU-F isolation strategy, with the addition of CD106 (VCAM-1) as another MSC marker [28]. Sorting for double-positive cells (Stro-1+CD106+) yielded cell fractions highly enriched for CFU-F [28]. Similar to Stro-1, CD106 expression appears to decline in MSCs at later passages $[17,29,30]$. In contrast to CD105 and CD73, CD106 expression is also strongly downregulated in MSCs after differentiation to adipo-, osteo-, and chondrocytes, suggesting that it may indeed be a marker of the most potent/undifferentiated cells within expanded MSC cultures
[31]. Another recently proposed possibility is that similar to Stro-1, CD106 (VCAM-1) expression on cultured MSCs is also related to their homing, migration, and adhesion capabilities [29].

Based on these and similar published findings, one can conclude that there exist two categories of markers for cultured MSCs. One category includes molecules that are stably expressed in vitro, with little difference between donors and little correlation with culture's in vitro history and ageing status (such as CD73, CD90, and CD105). The other, "second-tier" group of markers contains molecules which show dependency on donor or culture "age" or any other variables such as cell homing/attachment properties or cell seeding density (such as Stro-1 or CD106). Another example is PODXL, a sialomucin in the CD34 family, which marks highly proliferative MSCs in low-density, low-passage cultures and is downregulated in high-density cultures [33]. It is tempting to speculate that second-tier markers may be reflective of the MSC maturity or potency status at the single-cell level; if this stands true, a combination of markers from both groups will be needed for quality-control of MSC batches with characterized levels of potency. A concerted effort from different laboratories is needed to validate previously reported "second-tier" markers in respect to donor age, culture conditions, and seeding densities and to validate correlations and reproducibility between different centers.

A good example of such joint effort can be illustrated in Wagner et al., where candidate gene expression markers were validated in 4 centers across Europe [34]. High variability between centers was found [34] and the measurement of MSC methylation status was proposed to be a better way of monitoring in vitro MSC ageing [34, 35]. Alternatively, the lengths of telomeres in cultured MSCs may serve as a "true" indicator of MSC age in culture. Gradual telomere shortening in cultured MSCs was first documented by Banfi et al. [23] and further demonstrated by Baxter et al. [24] and other independent investigators [17, 36, 37]. It is noteworthy, however, that telomere lengths in human populations are heritable, showing a very high degree of donor-to-donor variability [38]. Similar to "second-tier" surface markers described previously, the utility of telomere length analysis as a measure of MSC "ageing" status may be limited to a single MSC batch at different stages of manufacture, rather than for comparison between batches from different donors. Such analysis may be very useful for bulk manufacture of MSCs for allogeneic use, whereby the rate of telomere erosion between passages can be seen as an indicator of their overall proliferative potency.

What about markers indicative of MSC propensity to differentiate? CD106 was proposed to be such marker by Fukiage et al. who showed that CD106+ BM MSCs were less osteogenic and more adipogenic than CD106-MSCs [39]. In this respect it is noteworthy that MSC proliferative and overall differentiation capacities are known to be intricately linked. It is now broadly accepted that aged, presenescent MSCs have a significantly reduced differentiation capacity towards adipogenic and chondrogenic lineages compared to early-passage MSCs (reviewed in Sethe et al. [40]). This 
TABLE 1: Surface antigen expression on cultured MSCs from different species.

\begin{tabular}{|c|c|c|c|c|c|c|c|c|c|c|c|}
\hline $\begin{array}{l}\text { Surface } \\
\text { antigen }\end{array}$ & Human & Mouse** & Rat & Rabbit & Primate & Dog & Pig & Goat & Sheep & Cow & Horse \\
\hline \multirow{3}{*}{ CD13 } & $++[72]$ & $-[73]^{*}$ & & & $\mathrm{NC}[72]$ & NC [72] & $\mathrm{NC}[72]$ & $\mathrm{NC}[72]$ & $\mathrm{NC}[72]$ & NC [74] & \\
\hline & $++[75]$ & $+[76]^{*}$ & & & & & & & & & \\
\hline & $++[77]$ & & & & & & & & & & \\
\hline \multirow{5}{*}{$\mathrm{CD} 29$} & $++[72]$ & $++[78]^{*}$ & $++[79]^{*}$ & $++[80]$ & $\mathrm{NC}[72]$ & $\mathrm{NC}[72]$ & $\mathrm{NC}[72]$ & $\mathrm{NC}[72]$ & $\mathrm{NC}[72]$ & & $++[59]$ \\
\hline & $++[81]$ & $++[73]^{*}$ & $++[82]^{*}$ & & & $+[83]$ & $++[81]$ & & $++[84]^{*}$ & & $++[62]^{*}$ \\
\hline & $++[6]$ & & $++[58]^{*}$ & & & & $++[46]$ & & $++[85]^{*}$ & & \\
\hline & $++[75]$ & & & & & & $++[47]$ & & & & \\
\hline & $++[77]$ & & & & & & & & & & \\
\hline \multirow{3}{*}{ CD31 } & $-[72]$ & $-[78]^{*}$ & & & $\mathrm{NC}[72]$ & $\mathrm{NC}[72]$ & $\mathrm{NC}[72]$ & $\mathrm{NC}[72]$ & $\mathrm{NC}[72]$ & & \\
\hline & $-[81]$ & $-[86]^{*}$ & & & & & $-[81]$ & & $-[84]^{*}$ & & \\
\hline & $-[75]$ & & & & & & $-[46]$ & & $-[85]^{*}$ & & \\
\hline \multirow{4}{*}{ CD34 } & $-[72]$ & $-[78]^{*}$ & & $+-[80]$ & $\mathrm{NC}$ [72] & $\mathrm{NC}[72]$ & $\mathrm{NC}[72]$ & $\mathrm{NC}[72]$ & $-[61]$ & & $-(\mathrm{CND})[59]$ \\
\hline & $-[81]$ & $+-[73]^{*}$ & & & $-[87]$ & $-[83]^{*}$ & $-[81]$ & & $\mathrm{NC}[72]$ & & \\
\hline & $-[6]$ & $-[76]^{*}$ & & & & & & & & & \\
\hline & $-[9]$ & $+[86]^{*}$ & & & & & & & & & \\
\hline \multirow{4}{*}{ CD44 } & $++[72]$ & $++[78]^{*}$ & $+[82]^{*}$ & & $\mathrm{NC}[72]$ & $\mathrm{NC}[72]$ & $\mathrm{NC}[72]$ & $\mathrm{NC}[72]$ & $++[61]$ & $++[74]$ & $-[59]$ \\
\hline & $++[81]$ & $++[73]^{*}$ & & & & $+[83]^{*}$ & $++[81]$ & & $\mathrm{NC}[72]$ & & $+[62]^{*}$ \\
\hline & $++[6]$ & & & & & & $++[46]$ & & $++[84]$ & & \\
\hline & $++[77]$ & & & & & & & & $++[85]$ & & \\
\hline \multirow{2}{*}{ CD49e } & $++[81]$ & $++[73]^{*}$ & $++[79]^{*}$ & & & & $-(\mathrm{CND})[81]$ & & & & \\
\hline & $++[77]$ & & & & & & & & & & \\
\hline \multirow{4}{*}{ CD45 } & $-[72]$ & $-[78]^{*}$ & $-[79]^{*}$ & & $-[87]$ & NC [72] & $\mathrm{NC}[72]$ & $\mathrm{NC}[72]$ & $-[61]^{*}$ & $+-[74]^{*}$ & $\overline{-(\mathrm{CND})[59]}$ \\
\hline & $-[81]$ & $+-[73]^{*}$ & $+-[82]^{*}$ & & & $-[83]^{*}$ & $-[81]^{*}$ & & $\mathrm{NC}[72]$ & & \\
\hline & $-[6]$ & $-[76]^{*}$ & $+-[58]^{*}$ & & & & $-[47]$ & & $-[84]$ & & \\
\hline & $-[9]$ & $-[86]^{*}$ & & & & & & & & & \\
\hline \multirow{4}{*}{ CD73 } & $++[72]$ & $+-[73]^{*}$ & $++[79]^{*}$ & & $++[72]$ & $-[72]$ & $-[72]$ & $-[72]$ & $-[72]$ & $\mathrm{NC}[74]$ & $-[59]$ \\
\hline & $++[9]$ & & $++[88]^{*}$ & & & & & & & & \\
\hline & $++[75]$ & & & & & & & & & & \\
\hline & $++[77]$ & & & & & & & & & & \\
\hline \multirow{5}{*}{ CD90 } & $++[72]$ & $++[73]^{*}$ & $++[79]^{*}$ & & $++[72]$ & $-[72]$ & $++[72]$ & $-[72]$ & $-[72]$ & & $++[59]$ \\
\hline & $++[81]$ & $+[76]^{*}$ & $++[82]^{*}$ & & & $+[83]$ & $++[81]$ & & & & \\
\hline & $++[6]$ & $-[86]^{*}$ & $++[58]^{*}$ & & & & $++[46]$ & & & & \\
\hline & $++[9]$ & & $++[88]^{*}$ & & & & $++[47]$ & & & & \\
\hline & $++[77]$ & & & & & & & & & & \\
\hline \multirow{5}{*}{ CD105 } & $++[72]$ & $+[78]^{*}$ & $++[79]^{*}$ & & $++[72]$ & $-[72]$ & $-[72]$ & $-[72]$ & $+-[61]$ & $\mathrm{NC}[74]$ & $-[59]$ \\
\hline & $++[81]$ & $++[73]^{*}$ & & & $+[87]$ & $-[83]$ & $\mathrm{NC}[81]$ & & $-[72]$ & & \\
\hline & $++[6]$ & & & & & & $++[47]$ & & & & \\
\hline & $++[9]$ & & & & & & & & & & \\
\hline & $++[77]$ & & & & & & & & & & \\
\hline \multirow{3}{*}{ CD146 } & $++[72]$ & & & & $++[72]$ & $+[72]$ & $++[72]$ & $-[72]$ & $++[72]$ & & \\
\hline & $++[81]$ & & & & & & $+[81]$ & & & & \\
\hline & $++[77]$ & & & & & & & & & & \\
\hline \multirow{3}{*}{ CD166 } & $++[81]$ & $+-[73]^{*}$ & & & & & $-[81]$ & & $++[85]$ & $++[74]$ & \\
\hline & $++[75]$ & & & & & & & & & & \\
\hline & $++[77]$ & & & & & & & & & & \\
\hline
\end{tabular}


TABle 1: Continued.

\begin{tabular}{|c|c|c|c|c|c|c|c|c|c|c|c|}
\hline $\begin{array}{l}\text { Surface } \\
\text { antigen }\end{array}$ & Human & Mouse** & Rat & Rabbit & Primate & Dog & Pig & Goat & Sheep & Cow & Horse \\
\hline \multirow{2}{*}{$\mathrm{CD} 271$} & $+-[72]$ & & & & $+[72]$ & $+-[72]$ & $+-[72]$ & $+-[72]$ & $+-[72]$ & & \\
\hline & $+-[81]$ & & & & & & $+-[81]$ & & & & \\
\hline \multirow{4}{*}{$\begin{array}{l}\text { c-Kit } \\
\text { (CD117) }\end{array}$} & $-[81]$ & $++[78]^{*}$ & & & & & $-[81]$ & & & & \\
\hline & & $+-[73]^{*}$ & & & & & & & & & \\
\hline & & $-[76]^{*}$ & & & & & & & & & \\
\hline & & $-[86]^{*}$ & & & & & & & & & \\
\hline \multirow{4}{*}{ Sca-1 } & $-[72]$ & $++[78]^{*}$ & & & $-[72]$ & $-[72]$ & $-[72]$ & $-[72]$ & $-[72]$ & & \\
\hline & $-[81]$ & $++[73]^{*}$ & & & & & $-[81]$ & & & & \\
\hline & & $++[76]^{*}$ & & & & & & & & & \\
\hline & & $++[86]^{*}$ & & & & & & & & & \\
\hline \multirow{4}{*}{ SSEA4 } & $++[72]$ & $++[89]^{*}$ & & & $++[72]$ & $-[72]$ & $-[72]$ & $+[72]$ & $-[72]$ & & \\
\hline & $++[81]$ & & & & & & NC [81] & & & & \\
\hline & $++[89]$ & & & & & & & & & & \\
\hline & $++[77]$ & & & & & & & & & & \\
\hline \multirow{2}{*}{ Stro-1 } & $++[81]$ & & $++[79]^{*}$ & & & & $+-[81]$ & & $-[85]$ & & \\
\hline & $++[26]$ & & & & & & & & & & \\
\hline \multirow{2}{*}{$\begin{array}{l}\text { W8-B2/ } \\
\text { MSCA-1 }\end{array}$} & $+[72]$ & & & & $+[72]$ & $+[72]$ & $+[72]$ & $++[72]$ & $+-[72]$ & & \\
\hline & $+[81]$ & & & & & & $+[81]$ & & & & \\
\hline
\end{tabular}

* Species-specific antibody (all others are antihuman antibodies). NC: no cross-reactivity; CND: cross-reactivity not determined. Symbols indicate marker expression levels: -: no expression; +-: <5\% expression; +: 5-50\% expression, ++: $50-100 \%$ expression. ** Markers specific for MSCs and MPCs are included due to confusion in terminology.

implies that measuring the MSC senescence status can in fact be indicative, to some degree, of their multipotentiality. At the clonal level, it has been recently shown that the most proliferative, tripotential clones are rapidly growing, whereas bi- and unipotential clones expand slower [41]. As early as 2000, Muragia et al. demonstrated that the majority of $\mathrm{BM}$ CFU-Fs are in fact unipotential towards osteogenesis [42]. Standard MSC cultures are composed of a mixture of uni-, bi-, and tripotential CFU-Fs and their precise ratio and relative rates of growth, in our opinion, determine the levels of multipotentiality of standard MSC cultures. General decline in MSC multipotentiality during extended passaging seems to correlate well with a known decline in CD106+ cells $[17,29,30]$ supporting the idea that CD106 may indeed mark the most immature, multipotent (rather than uni- or bipotent) progenitors.

\section{BM MSC Markers in Animal Models}

Animal models have become crucial for preclinical testing of MSC preparations. MSCs from larger animals (dog, sheep, goat, and horse) are normally used for a preclinical evaluation of bone and joint tissue regeneration from MSCs $[43,44]$. Such large animal models carry significant logistical and financial considerations but can in fact be useful in some cases whereby veterinary patients can be recruited (such as race horses) [45]. Pig is emerging as the species of choice for preclinical evaluation of the immunomodulatory effects of MSC in terms of both cardiac repair [46] and prevention of immune rejection after solid organ transplant
[47]. Smaller animals like rats are frequently used for testing neurological and brain injury repair [48]. Mice have been used to study the immunomodulatory properties of MSCs in both autoimmune [49, 50] and neurological [51] disease models. Although mouse models provide proof-ofprinciple and allow testing of MSC function in a variety of diseases including arthritis [52, 53], they often fail, in our opinion, to adequately mirror the human diseases. Naturally occurring diseases in larger domestic animals can be more suitable as disease models for some human genetic and acquired diseases and could help to define the potential and therapeutic efficiency and safety of stem cells therapies [54].

Defining the phenotype of MSCs from different animal species is complicated by a lack of species-specific antibodies (Table 1). Whilst there is a larger selection of species-specific antibodies for the more commonly used small animals such as mouse and rat, species-specific antibodies for larger animals are less common. In the absence of species-specific antibodies for common MSC-selective markers in large animals, the majority of work to date has been performed using anti-human antibodies which do not always cross-react with these species. It should also be noted that there is an increasing amount of data available on MSC phenotype in various species as determined by immunohistochemistry and cytochemical techniques [55-58], but given the semiquantitative nature of this data this paper will focus on the MSC phenotype as determined by flow cytometry.

Many of the antigens which are known not to be expressed on MSCs in humans, such as CD31, CD34, and CD45, are also absent on MSCs from other species (Table 1). 
Whilst likely to be a true finding, even negative results need to be interpreted with caution as the cross-reactivity of the anti-human antibody clones used have not always been fully evaluated on the species being investigated. Of the publications considered in this paper (Table 1) only a minority give information on whether the anti-human antibodies being used have been validated for cross-reactivity with the target species. Whilst some investigators state that they have not fully validated the antibody cross-reactivity [59], others have screened antibodies of interest for positive expression by flow cytometry on other cell types from the same species $[60,61]$. Some investigators have gone further in their evaluation, by performing western blot and immunoprecipitation experiments on both MSCs and control cell types from the same species [62].

Some of the most consistently expressed markers across species are CD29 and CD44, but since these molecules are expressed by multiple cells types in many tissues [63], their lack of specificity may limit their usefulness as a marker for MSCs. CD44 has been recently proposed to be involved in stem cell pluripotency and mark several types of cancer stem cells [64]; its numerous other functions, including roles in cell-matrix interaction, homing, adhesion, matrix assembly, and apoptosis resistance [64], preclude, in our opinion, its widespread use as a robust marker of MSCs.

As mentioned earlier, the current criteria for human MSCs put emphasis on the positive expression of CD73, CD90, and CD105 [9]; however none of these markers are expressed by all species (Table 1). CD90 shows strong expression in the majority of species tested but is absent on MSCs in goats and sheep. Interestingly, the actual tissue distribution of CD90 expression varies with species [65-68] and in humans CD90 expression is more restricted compared to mice $[16,69,70]$. Furthermore, different strains of mice express two alternative CD90 antigens (CD90.1/Thy1.1 or CD90.2/Thy1.2), which only differ by one amino acid [71]. This puts into question the validity of using anti-human CD90 antibodies for other species since this antigen does not appear to be well conserved. In our opinion, the variable levels or complete lack of expression of CD73, CD105 and CD90 in MSCs from some animal species using anti-human antibodies is likely to indicate a lack of antibody crossreactivity. Species-specific antibodies would be required to confirm the true expression pattern of these molecules.

Whilst expression of the same antigens on MSCs across different species is not essential for defining useful MSC markers, the advantages it would bring to preclinical evaluation in animal models do make this a desirable consideration. A number of known human MSC markers have yet to be tested in all species (Table 1). CD146, for example, shows consistent strong expression in humans, pigs, and sheep but remains to be tested in the largest animal models such as cows and horses. Some markers such as CD271 and W8-B2/MSCA-1 have been used to prospectively isolate MSCs in humans [90], a subject that will be expanded on later. The lack of expression of CD271 on cultured MSCs from any species is perhaps predictable given that CD271 is downregulated on culture of human MSCs [55, 91, 92]. This raises the possibility that the best markers for identification may be different between freshly isolated and culture-expanded cells. Given that expression is observed in most of the species tested, W8-B2/MSCA-1 is an interesting candidate for further investigation. The consistent but low expression (Table 1) could be due to its low-level, homogenous expression on all cultured MSCs or due to a small, but distinct proportion of W8-B2 positive cells within animal MSC cultures; this is something to be considered in future studies addressing W8-B2 expression in MSCs from other animal species such as mouse, rat, and horse.

\section{Markers for Prospective Isolation of BM MSCs in Humans and Animals}

The establishment of robust markers for prospective isolation of MSCs is of utmost importance. Firstly, it is needed to put MSCs on the same footing as HSCs, in which the in vivo phenotype is well established [93] allowing the direct study of the function of uncultured HSCs in animal models [94]. Secondly, if the phenotype of plasticadherent culture-initiating MSCs was known, the contribution of other adherent cells from the marrow (hematopoietic progenitors, monocytic-, and endothelial-lineage cells) to MSC "plasticity" and other characteristics would have been much clearer. Additionally, freshly isolated MSCs that have not been artificially "aged" in culture are likely to have higher multipotential and proliferative capacities compared to their culture-expanded progeny. Finally, MSC cultures established from the selected native MSCs free of contaminating (and potentially inhibitory) plastic adherent cells may have stronger immunosuppressive and lymphohematopoietic engraftment-promoting properties, as shown recently [95]. Stronger immunosuppressive effects may at least in part be mediated by an enhanced support of highly suppressive naive T-regulatory cells [96].

The up-to-date list of candidate markers used to isolate human BM MSCs has been extensively reviewed elsewhere [92, 97, 98]. Here we will discuss several issues that have not been previously highlighted: firstly, the cross-reaction of these candidate markers with other BM cells. As seen in Table 2, almost every previously proposed human BM MSC marker is also expressed on other cell types found in the marrow, be it of hematopoietic or endothelial lineage. This does not pose a significant problem in current MSC manufacture protocols, in which MSCs undergo several rounds of passaging, leading to a gradual loss of these contaminating cells. However if one considers manufacture of MSC-seeded scaffolds in rotating bioreactors [99], adherent contaminating cells may by highly unfavorable, taking up the space and oxygen from growing MSCs. The same considerations apply when freshly purified, uncultured MSCs are used. In one clinical study BM MSCs were concentrated using a commercial concentrator device and it was found that a graft containing $>1000 \mathrm{CFU}-\mathrm{F} / \mathrm{cm}^{3}$ was effective in healing nonunion fractures following percutaneous injection [100]. However it was noted that transplanted MSCs had to compete with other transplanted cells for oxygen and "one way to optimize cell survival is to limit the transplanted 
TABLE 2: Expression of common MSC markers on other cell types found in human bone marrow.

\begin{tabular}{|c|c|c|c|c|c|c|c|c|c|c|c|c|}
\hline & $\mathrm{CD} 13$ & CD29 & CD44 & CD73 & CD90 & CD105 & CD106 & CD146 & CD200 & $\mathrm{CD} 271$ & STRO-1 & SSEA-4 \\
\hline $\begin{array}{l}\text { Mesenchymal } \\
\text { Stromal Cells }\end{array}$ & $+[91]$ & $+[101]$ & $+[102]$ & $+[6]$ & $+[9]$ & $+[6]$ & $+[90]$ & $+[103]$ & $+[77]$ & $+[91]$ & $+[26]$ & $+[89]$ \\
\hline $\begin{array}{l}\text { Haematopoietic } \\
\text { Stem Cell }\end{array}$ & & & $+[104]$ & & $+[16]$ & & & & & & & \\
\hline $\begin{array}{l}\text { Lymphoid } \\
\text { lineage }\end{array}$ & & $+[105]$ & $+[106]$ & $+[107]$ & & & & & $+[108]$ & & & \\
\hline Myeloid lineage & $+[109]$ & $+[105]$ & $+[110]$ & & & $+[111]$ & & & & & & \\
\hline $\begin{array}{l}\text { Megakaryocytic } \\
\text { lineage }\end{array}$ & & $+[112]$ & & & & & & & & & & $+[113]$ \\
\hline $\begin{array}{l}\text { Erythroid } \\
\text { lineage }\end{array}$ & & & $+[110]$ & & & & & & & $+[57]$ & $+[26]$ & $+[114]$ \\
\hline $\begin{array}{l}\text { Endothelial } \\
\text { lineage cells }\end{array}$ & $+[115]$ & $+[116]$ & $+[110]$ & $+[21]$ & & $+[117]$ & $+[118]$ & $+[103]$ & $+[108]$ & & $+[119]$ & $+[120]$ \\
\hline
\end{tabular}

cells to those that contribute to the formation of bone (i.e., exclude all others)" [100].

The depletion of undesirable cells and hence an enrichment of human BM MSCs can be achieved by positive selection with markers having the least cross-reactivity with other cell types (Table 2). Notably, CD271 and W8-B2/MSCA1 have an additional advantage of being highly conserved between species (Table 1) making them usable for fresh MSC isolation in large animals. Specifically, CD271 was found useful for the isolation of BM MSCs in bovine [74] and porcine [81] models. The function of CD271 on MSCs remains incompletely understood. In human jaw periosteum-derived cells, CD271+ and CD271- populations were shown to differ in their mineralizing capacities suggesting that CD271 could "be considered an early surface marker of osteogenic capacity" [121]. In dental pulp stem cell cultures, CD271 was proposed to have a role in inhibiting their differentiation [122]. In another view, CD271 is a general neural crest stem cell marker [123], thus putatively explaining its expression on melanoma cancer stem cells [123] and, potentially, on native follicular epithelial cells [124].

W8-B2/MSCA-1 antigen is identical to tissue nonspecific alkaline phosphatase (TNAP), an enzyme known to be expressed at high levels in human liver, bone, and kidney and in embryonic stem cells $[125,126]$. In a knockout mouse model, TNAP was shown to promote bone mineralization by providing free inorganic phosphate and by degrading inorganic pyrophosphate, which inhibits mineralization [127]. The STRO-3 antibody has also been shown to bind to TNAP and be a good marker of uncultured BM MSCs [128]. Notably, we demonstrated the expression of bone/liver alkaline phosphatase on the surface of BM CD271+ cells in 2006 [92].

It is generally accepted that the sole positive selection for CD271 may not be sufficient to achieve $100 \%$ purity for human MSCs. The removal or "gating out" of hematopoietic lineage cells is commonly required, as CD271 is expressed at low levels on hematopoietic progenitor cells of the erythroid lineage $[57,129]$. When gated only on the nonhematopoietic (CD45-/low fraction), the human BM MSC population (CD73+CD105+) can be easily found [56]. In our hands however, CD105 appears to be less discriminative than CD271, CD73, or CD90 (Figure 1) indicating that CD271 and/or CD73 gating is possibly the best way for identifying and sorting human BM MSCs to the highest levels of purity $[129,130]$. Several other studies have been performed recently aimed at achieving high-purity BM MSCs using a combination of CD271 and markers other than CD73, CD105, or CD90. For example, CD146 has attracted a lot of interest recently, based on seminal papers by Sacchetti et al. [131] and Crisan et al. [132] linking CD146 expression on MSCs with their pericyte topography and function. More recently however, it was shown that CD146 expression on CD271+ MSCs correlates more with their in situ localization [57] and/or the age of donor [133]. Perhaps more promising for the refinement of the MSC purification strategy to $100 \%$ purity would be further selection for W8B2/MSCA-1 expression [90, 98]; these findings are awaiting further confirmation by other independent investigators.

\section{Molecular Markers of Purified Uncultured MSCs}

It would be advantageous if a molecular marker of MSCs, in the manner of oct-4 for embryonic stem cells [134], could be found, helping to identify MSCs in other tissues and organs. To date, this has proven elusive. Instead, the simultaneous expression of transcription factors (TFs) triggering several mesenchymal lineages (including, but not limited to, adipogenic, chondrogenic, and osteogenic) has been reported in native BM MSCs $[28,57]$ or their expanded progeny [135]. We have recently found strong expression of pericytic and hematopoiesis-supportive genes in CD271+ BM MSCs [136], confirming and extending earlier findings obtained using Stro-1 based MSC selection [137]. We additionally observed prominent Wnt pathway signaling activity in uncultured BM MSCs, which was significantly stronger compared to cultured MSCs or skin fibroblasts [136]. Further advance in qPCR methodology allowing the simultaneous assessment of thousands of candidate genes 


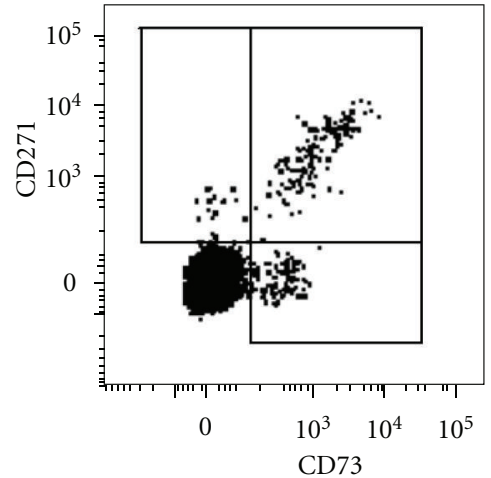

(a)

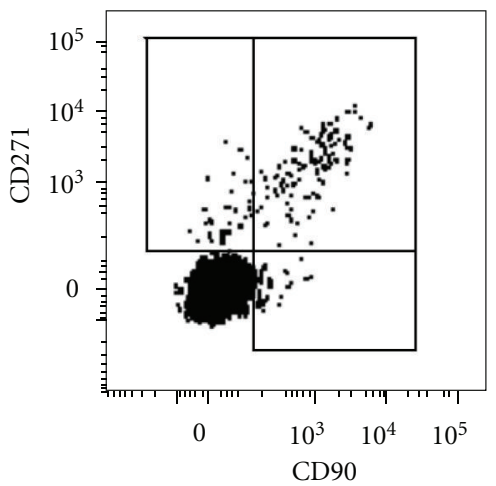

(b)

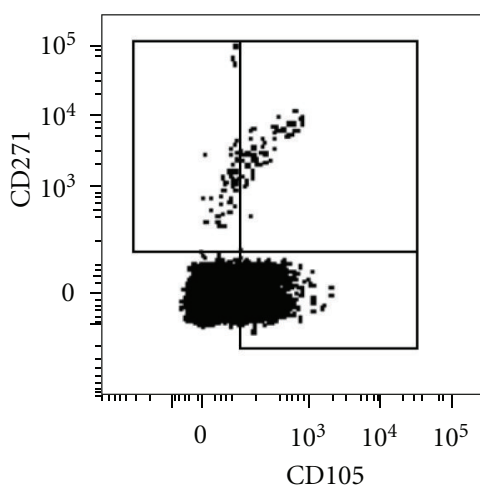

(c)

Figure 1: Coexpression of (a) CD271/CD73, (b) CD271/CD90, and (c) CD271/CD105 on CD45-/low cells in human bone marrow aspirates determined by flow cytometry. Mononuclear cells were isolated from bone marrow aspirates and stained with antibodies as previously described [32].

in rare, sorted MSCs is likely to reveal novel gene(s) with robust, strong expression and high selectivity. These new gene transcripts could be used as molecular markers of marrow MSCs leading to clear demonstration of their in vivo function using knock-out animal models.

\section{Concluding Remarks}

At present, we cannot definitely conclude that MSCs resident in different tissues are the same or even very similar. For example, adipose-derived MSCs express CD34 [138] whereas BM MSCs do not (Table 1). CD271 is expressed in the synovium [139], but the phenotype of synovial MSCs may be much broader [140]. W8-B2/MSCA-1 is expressed by BM MSCs but not placenta-derived MSCs [141]. This suggests that the search for novel markers, intricately linked to the fundamental MSC function, including both surface and molecular markers, should continue. The knowledge of the phenotype and gene expression profile of BM MSCs in their original niche should undoubtedly help to develop new methodologies for expanding these MSCs "in their native state", via the design of novel biomimetic scaffolds, surfaces, attachment molecules or cytokine cocktails. This is likely to yield MSC-based therapeutic products with significantly improved quality and predictable biological behaviors. Testing of novel purified and expanded MSCbased products in large animal models will allow through pre-clinical evaluation of novel products prior to clinical trials in humans. Additionally, a broader knowledge of native BM MSCs in diseases related to bone physiology and blood cell development, including osteoporosis and leukemias, will lead to a much better understanding of the role of MSCs in the development of these diseases, potentially identifying new targets for therapy.

\section{Acknowledgments}

S. A. Boxall is supported by PurStem-FP7 project no. 223298. E. Jones holds funding from Wellcome Trust/EPSRC through WELMEC, a Centre of Excellence in Medical Engineering, under Grant no. WT088908/Z/09/Z. The authors gratefully acknowledge the help of Dr Thomas Baboolal for his critical evaluation of this paper.

\section{References}

[1] A. J. Friedenstein, N. V. Latzinik, U. F. Gorskaya, and S. Y. Sidorovich, "Radiosensitivity and postirradiation changes of bone marrow clonogenic stromal mechanocytes," International Journal of Radiation Biology, vol. 39, no. 5, pp. 537-546, 1981.

[2] A. J. Friedenstein, N. W. Latzinik, A. G. Grosheva, and U. F. Gorskaya, "Marrow microenvironment transfer by heterotopic transplantation of freshly isolated and cultured cells in porous sponges," Experimental Hematology, vol. 10, no. 2, pp. 217-227, 1982.

[3] A. J. Friedenstein, R. K. Chailakhyan, and U. V. Gerasimov, "Bone marrow osteogenic stem cells: in vitro cultivation and transplantation in diffusion chambers," Cell and Tissue Kinetics, vol. 20, no. 3, pp. 263-272, 1987.

[4] A. J. Friedenstein, "Precursor cells of mechanocytes," International Review of Cytology, vol. 47, pp. 327-352, 1976.

[5] A. I. Caplan, "Mesenchymal stem cells," Journal of Orthopaedic Research, vol. 9, no. 5, pp. 641-650, 1991.

[6] M. F. Pittenger, A. M. Mackay, S. C. Beck et al., "Multilineage potential of adult human mesenchymal stem cells," Science, vol. 284, no. 5411, pp. 143-147, 1999.

[7] F. P. Barry, R. E. Boynton, S. Haynesworth, J. M. Murphy, and J. Zaia, "The monoclonal antibody SH-2, raised against human mesenchymal stem cells, recognizes an epitope on endoglin (CD105)," Biochemical and Biophysical Research Communications, vol. 265, no. 1, pp. 134-139, 1999.

[8] F. Barry, R. Boynton, M. Murphy, and J. Zaia, "The SH-3 and $\mathrm{SH}-4$ antibodies recognize distinct epitopes on CD73 from human mesenchymal stem cells," Biochemical and Biophysical Research Communications, vol. 289, no. 2, pp. 519-524, 2001.

[9] M. Dominici, K. Le Blanc, I. Mueller et al., "Minimal criteria for defining multipotent mesenchymal stromal cells. The International Society for Cellular Therapy position statement," Cytotherapy, vol. 8, no. 4, pp. 315-317, 2006. 
[10] A. Ode, J. Kopf, A. Kurtz et al., "CD73 and CD29 concurrently mediate the mechanically induced decrease of migratory capacity of mesenchymal stromal cells," European Cells and Materials, vol. 22, pp. 26-42, 2011.

[11] T. Eckle, L. Füllbier, M. Wehrmann et al., "Identification of ectonucleotidases CD39 and CD73 in innate protection during acute lung injury," Journal of Immunology, vol. 178, no. 12, pp. 8127-8137, 2007.

[12] S. M. M. Haeryfar and D. W. Hoskin, "Thy-1: more than a mouse pan-T cell marker," Journal of Immunology, vol. 173, no. 6, pp. 3581-3588, 2004.

[13] A. F. Williams and J. Gagnon, "Neuronal cell Thy-1 glycoprotein: homology with immunoglobulin," Science, vol. 216, no. 4547, pp. 696-703, 1982.

[14] H. T. He, P. Naquet, D. Caillol, and M. Pierres, "Thy-1 supports adhesion of mouse thymocytes to thymic epithelial cells through a $\mathrm{Ca}^{2+}$-independent mechanism," The Journal of Experimental Medicine, vol. 173, no. 2, pp. 515-518, 1991.

[15] A. Saalbach, U. F. Haustein, and U. Anderegg, "A ligand of human Thy- 1 is localized on polymorphonuclear leukocytes and monocytes and mediates the binding to activated Thy1-positive microvascular endothelial cells and fibroblasts," Journal of Investigative Dermatology, vol. 115, no. 5, pp. 882 888,2000 .

[16] W. Craig, R. Kay, R. L. Cutler, and P. M. Lansdorp, "Expression of Thy-1 on human hematopoietic progenitor cells," The Journal of Experimental Medicine, vol. 177, no. 5, pp. 1331-1342, 1993.

[17] E. Jones, A. English, S. M. Churchman et al., "Large-scale extraction and characterization of CD271+ multipotential stromal cells from trabecular bone in health and osteoarthritis: implications for bone regeneration strategies based on uncultured or minimally cultured multipotential stromal cells," Arthritis and Rheumatism, vol. 62, no. 7, pp. 19441954, 2010.

[18] E. A. Jones, A. English, K. Henshaw et al., "Enumeration and phenotypic characterization of synovial fluid multipotential mesenchymal progenitor cells in inflammatory and degenerative arthritis," Arthritis and Rheumatism, vol. 50, no. 3, pp. 817-827, 2004.

[19] M. Ishii, C. Koike, A. Igarashi et al., "Molecular markers distinguish bone marrow mesenchymal stem cells from fibroblasts," Biochemical and Biophysical Research Communications, vol. 332, no. 1, pp. 297-303, 2005.

[20] N. L. M. Chan, A. Bourdeau, S. Vera et al., "Umbilical vein and placental vessels from newborns with hereditary haemorrhagic telangiectasia type 1 genotype are normal despite reduced expression of endoglin," Placenta, vol. 25, no. 2-3, pp. 208-217, 2004.

[21] S. Narravula, P. F. Lennon, B. U. Mueller, and S. P. Colgan, "Regulation of endothelial CD73 by adenosine: paracrine pathway for enhanced endothelial barrier function," Journal of Immunology, vol. 165, no. 9, pp. 5262-5268, 2000.

[22] C. M. Digirolamo, D. Stokes, D. Colter, D. G. Phinney, R. Class, and D. J. Prockop, "Propagation and senescence of human marrow stromal cells in culture: a simple colonyforming assay identifies samples with the greatest potential to propagate and differentiate," British Journal of Haematology, vol. 107, no. 2, pp. 275-281, 1999.

[23] A. Banfi, G. Bianchi, R. Notaro, L. Luzzatto, R. Cancedda, and R. Quarto, "Replicative aging and gene expression in longterm cultures of human bone marrow stromal cells," Tissue Engineering, vol. 8, no. 6, pp. 901-910, 2002.
[24] M. A. Baxter, R. F. Wynn, S. N. Jowitt, J. E. Wraith, L. J. Fairbairn, and I. Bellantuono, "Study of telomere length reveals rapid aging of human marrow stromal cells following in vitro expansion," Stem Cells, vol. 22, no. 5, pp. 675-682, 2004.

[25] W. Wagner, P. Horn, M. Castoldi et al., "Replicative senescence of mesenchymal stem cells: a continuous and organized process," PLoS One, vol. 3, no. 5, Article ID e2213, 2008.

[26] P. J. Simmons and B. Torok-Storb, "Identification of stromal cell precursors in human bone marrow by a novel monoclonal antibody, STRO-1," Blood, vol. 78, no. 1, pp. 55-62, 1991.

[27] M. Bensidhoum, A. Chapel, S. Francois et al., "Homing of in vitro expanded Stro- $1^{-}$or Stro- $1^{+}$human mesenchymal stem cells into the NOD/SCID mouse and their role in supporting human CD34 cell engraftment," Blood, vol. 103, no. 9, pp. 3313-3319, 2004.

[28] S. Gronthos, A. C. W. Zannettino, S. J. Hay et al., "Molecular and cellular characterisation of highly purified stromal stem cells derived from human bone marrow," Journal of Cell Science, vol. 116, no. 9, pp. 1827-1835, 2003.

[29] E. M. Jung, O. Kwon, K. S. Kwon et al., "Evidences for correlation between the reduced VCAM-1 expression and hyaluronan synthesis during cellular senescence of human mesenchymal stem cells," Biochemical and Biophysical Research Communications, vol. 404, no. 1, pp. 463-469, 2011.

[30] S. Halfon, N. Abramov, B. Grinblat, and I. Ginis, "Markers distinguishing mesenchymal stem cells from fibroblasts are downregulated with passaging," Stem Cells and Development, vol. 20, no. 1, pp. 53-66, 2011.

[31] F. Liu, Y. Akiyama, S. Tai et al., "Changes in the expression of CD106, osteogenic genes, and transcription factors involved in the osteogenic differentiation of human bone marrow mesenchymal stem cells," Journal of Bone and Mineral Metabolism, vol. 26, no. 4, pp. 312-320, 2008.

[32] G. Cox, S. A. Boxall, P. V. Giannoudis et al., "High abundance of CD271(+) multipotential stromal cells (MSCs) in intramedullary cavities of long bones," Bone, vol. 50, no. 2 , pp. 510-517, 2012.

[33] R. H. Lee, M. J. Seo, A. A. Pulin, C. A. Gregory, J. Ylostalo, and D. J. Prockop, "The CD34-like protein PODXL and alpha6-integrin (CD49f) identify early progenitor MSCs with increased clonogenicity and migration to infarcted heart in mice," Blood, vol. 113, no. 4, pp. 816-826, 2009.

[34] W. Wagner, S. Bork, G. Lepperdinger et al., "How to track cellular aging of mesenchymal stromal cells?" Aging, vol. 2, no. 4, pp. 224-230, 2010.

[35] A. Schellenberg, Q. Lin, H. Schüler et al., "Replicative senescence of mesenchymal stem cells causes DNA-methylation changes which correlate with repressive histone marks," Aging, vol. 3, no. 9, pp. 873-888, 2011.

[36] M. M. Bonab, K. Alimoghaddam, F. Talebian, S. H. Ghaffari, A. Ghavamzadeh, and B. Nikbin, "Aging of mesenchymal stem cell in vitro," BMC Cell Biology, vol. 7, article 14, 2006.

[37] K. Mareschi, I. Ferrero, D. Rustichelli et al., "Expansion of mesenchymal stem cells isolated from pediatric and adult donor bone marrow," Journal of Cellular Biochemistry, vol. 97, no. 4, pp. 744-754, 2006.

[38] K. Nordfjäll, Å. Larefalk, P. Lindgren, D. Holmberg, and G. Roos, "Telomere length and heredity: indications of paternal inheritance," Proceedings of the National Academy of Sciences of the United States of America, vol. 102, no. 45, pp. 1637416378, 2005. 
[39] K. Fukiage, T. Aoyama, K. R. Shibata et al., "Expression of vascular cell adhesion molecule-1 indicates the differentiation potential of human bone marrow stromal cells," Biochemical and Biophysical Research Communications, vol. 365, no. 3, pp. 406-412, 2008.

[40] S. Sethe, A. Scutt, and A. Stolzing, "Aging of mesenchymal stem cells," Ageing Research Reviews, vol. 5, no. 1, pp. 91-116, 2006.

[41] S. Mareddy, R. Crawford, G. Brooke, and Y. Xiao, "Clonal isolation and characterization of bone marrow stromal cells from patients with osteoarthritis," Tissue Engineering, vol. 13, no. 4, pp. 819-829, 2007.

[42] A. Muraglia, R. Cancedda, and R. Quarto, "Clonal mesenchymal progenitors from human bone marrow differentiate in vitro according to a hierarchical model," Journal of Cell Science, vol. 113, no. 7, pp. 1161-1166, 2000.

[43] C. R. Chu, M. Szczodry, and S. Bruno, "Animal models for cartilage regeneration and repair," Tissue Engineering-Part B, vol. 16, no. 1, pp. 105-115, 2010.

[44] H. Dashtdar, H. A. Rothan, T. Tay et al., "A preliminary study comparing the use of allogenic chondrogenic predifferentiated and undifferentiated mesenchymal stem cells for the repair of full thickness articular cartilage defects in rabbits," Journal of Orthopaedic Research, vol. 29, no. 9, pp. 1336-1342, 2011.

[45] E. E. Godwin, N. J. Young, J. Dudhia, I. C. Beamish, and R. K. W. Smith, "Implantation of bone marrow-derived mesenchymal stem cells demonstrates improved outcome in horses with overstrain injury of the superficial digital flexor tendon," Equine Veterinary Journal, vol. 44, no. 1, pp. 25-32, 2011.

[46] T. Sato, Y. Iso, T. Uyama et al., "Coronary vein infusion of multipotent stromal cells from bone marrow preserves cardiac function in swine ischemic cardiomyopathy via enhanced neovascularization," Laboratory Investigation, vol. 91, no. 4, pp. 553-564, 2011.

[47] P. Comite, L. Cobianchi, M. A. Avanzini et al., "Isolation and ex vivo expansion of bone marrow-derived porcine mesenchymal stromal cells: potential for application in an experimental model of solid organ transplantation in large animals," Transplantation Proceedings, vol. 42, no. 4, pp. 1341-1343, 2010.

[48] H. Zhang, Z. Huang, Y. Xu, and S. Zhang, "Differentiation and neurological benefit of the mesenchymal stem cells transplanted into the rat brain following intracerebral hemorrhage," Neurological Research, vol. 28, no. 1, pp. 104112, 2006.

[49] J. Yu, C. Zheng, X. Ren et al., "Intravenous administration of bone marrow mesenchymal stem cells benefits experimental autoimmune myasthenia gravis mice through an immunomodulatory action," Scandinavian Journal of Immunology, vol. 72, no. 3, pp. 242-249, 2010.

[50] N. Grigoriadis, A. Lourbopoulos, R. Lagoudaki et al., "Variable behavior and complications of autologous bone marrow mesenchymal stem cells transplanted in experimental autoimmune encephalomyelitis," Experimental Neurology, vol. 230, no. 1, pp. 78-89, 2011.

[51] J. K. Lee, H. K. Jin, S. Endo, E. H. Schuchman, J. E. Carter, and J. S. Bae, "Intracerebral transplantation of bone marrow-derived mesenchymal stem cells reduces amyloidbeta deposition and rescues memory deficits in Alzheimer's disease mice by modulation of immune responses," Stem Cells, vol. 28, no. 2, pp. 329-343, 2010.
[52] F. Djouad, V. Fritz, F. Apparailly et al., "Reversal of the immunosuppressive properties of mesenchymal stem cells by tumor necrosis factor $\alpha$ in collagen-induced arthritis," Arthritis and Rheumatism, vol. 52, no. 5, pp. 1595-1603, 2005.

[53] S. T. Mohanty, L. Kottam, A. Gambardella et al., "Alterations in the self-renewal and differentiation ability of bone marrow mesenchymal stem cells in a mouse model of rheumatoid arthritis," Arthritis Research and Therapy, vol. 12, no. 4, article R149, 2010.

[54] L. L. Black, J. Gaynor, C. Adams et al., "Effect of intraarticular injection of autologous adipose-derived mesenchymal stem and regenerative cells on clinical signs of chronic osteoarthritis of the elbow joint in dogs," Veterinary Therapeutics, vol. 9, no. 3, pp. 192-200, 2008.

[55] N. Quirici, D. Soligo, P. Bossolasco, F. Servida, C. Lumini, and G. L. Deliliers, "Isolation of bone marrow mesenchymal stem cells by anti-nerve growth factor receptor antibodies," Experimental Hematology, vol. 30, no. 7, pp. 783-791, 2002.

[56] C. Martinez, T. J. Hofmann, R. Marino, M. Dominici, and E. M. Horwitz, "Human bone marrow mesenchymal stromal cells express the neural ganglioside GD2: a novel surface marker for the identification of MSCs," Blood, vol. 109, no. 10, pp. 4245-4248, 2007.

[57] A. Tormin, O. Li, J. C. Brune et al., "CD146 expression on primary nonhematopoietic bone marrow stem cells is correlated with in situ localization," Blood, vol. 117, no. 19, pp. 5067-5077, 2011.

[58] E. Karaoz, A. Aksoy, S. Ayhan, A. E. SarIboyacI, F. Kaymaz, and M. Kasap, "Characterization of mesenchymal stem cells from rat bone marrow: ultrastructural properties, differentiation potential and immunophenotypic markers," Histochemistry and Cell Biology, vol. 132, no. 5, pp. 533-546, 2009.

[59] B. Ranera, J. Lyahyai, A. Romero et al., "Immunophenotype and gene expression profiles of cell surface markers of mesenchymal stem cells derived from equine bone marrow and adipose tissue," Veterinary Immunology and Immunopathology, vol. 144, no. 1-2, pp. 147-154, 2011.

[60] C. De Schauwer, E. Meyer, G. R. Van de Walle, and A. Van Soom, "Markers of stemness in equine mesenchymal stem cells: a plea for uniformity," Theriogenology, vol. 75, no. 8, pp. 1431-1443, 2011.

[61] D. Mrugala, C. Bony, N. Neves et al., "Phenotypic and functional characterisation of ovine mesenchymal stem cells: application to a cartilage defect model," Annals of the Rheumatic Diseases, vol. 67, no. 3, pp. 288-295, 2008.

[62] C. H. Radcliffe, M. J. B. F. Flaminio, and L. A. Fortier, "Temporal analysis of equine bone marrow aspirate during establishment of putative mesenchymal progenitor cell populations," Stem Cells and Development, vol. 19, no. 2, pp. 269281, 2010.

[63] C. A. Lowell and T. N. Mayadas, "Overview: studying integrins in vivo," Methods in Molecular, vol. 757, pp. 369397, 2012.

[64] M. Zöller, "CD44: can a cancer-initiating cell profit from an abundantly expressed molecule?" Nature Reviews Cancer, vol. 11, no. 4, pp. 254-267, 2011.

[65] R. Dalchau and J. W. Fabre, "Identification and unusual tissue distribution of the canine and human homologues of Thy-1 $(\theta)$," The Journal of Experimental Medicine, vol. 149, no. 3, pp. 576-591, 1979. 
[66] S. Pont, "Thy-1: a lymphoid cell subset marker capable of delivering an activation signal to mouse T lymphocytes," Biochimie, vol. 69, no. 4, pp. 315-320, 1987.

[67] J. T. Kemshead, M. A. Ritter, S. F. Cotmore, and M. F. Greaves, "Human Thy-1: expression on the cell surface of neuronal and glial cells," Brain Research, vol. 236, no. 2, pp. 451-461, 1982.

[68] A. E. Reif and J. M. Allen, "The akr thymic antigen and its distribution in leukemias and nervous tissues," The Journal of Experimental Medicine, vol. 120, pp. 413-433, 1964.

[69] R. Dalchau, A. S. Daar, and J. W. Fabre, "The human Thy-1 molecule," Immunology Series, vol. 45, pp. 185-196, 1989.

[70] J. C. Mason, H. Yarwood, A. Tárnok et al., "Human Thy-1 is cytokine-inducible on vascular endothelial cells and is a signaling molecule regulated by protein kinase C," Journal of Immunology, vol. 157, no. 2, pp. 874-883, 1996.

[71] T. A. Rege and J. S. Hagood, "Thy-1 as a regulator of cell-cell and cell-matrix interactions in axon regeneration, apoptosis, adhesion, migration, cancer, and fibrosis," The FASEB Journal, vol. 20, no. 8, pp. 1045-1054, 2006.

[72] H. Rozemuller, H. J. Prins, B. Naaijkens, J. Staal, H. J. Bühring, and A. C. Martens, "Prospective isolation of mesenchymal stem cells from multiple mammalian species using cross-reacting anti-human monoclonal antibodies," Stem Cells and Development, vol. 19, no. 12, pp. 1911-1921, 2010.

[73] R. A. Pelekanos, J. Li, M. Gongora et al., "Comprehensive transcriptome and immunophenotype analysis of renal and cardiac MSC-like populations supports strong congruence with bone marrow MSC despite maintenance of distinct identities," Stem Cell Research, vol. 8, no. 1, pp. 58-73, 2012.

[74] E. A. Jones, A. Crawford, A. English et al., "Synovial fluid mesenchymal stem cells in health and early osteoarthritis: detection and functional evaluation at the single-cell level," Arthritis and Rheumatism, vol. 58, no. 6, pp. 1731-1740, 2008.

[75] B. Delorme and P. Charbord, "Culture and characterization of human bone marrow mesenchymal stem cells," Methods in Molecular Medicine, vol. 140, pp. 67-81, 2007.

[76] Y. Jiang, B. N. Jahagirdar, R. L. Reinhardt et al., "Pluripotency of mesenchymal stem cells derived from adult marrow," Nature, vol. 418, no. 6893, pp. 41-49, 2002.

[77] B. Delorme, J. Ringe, N. Gallay et al., "Specific plasma membrane protein phenotype of culture-amplified and native human bone marrow mesenchymal stem cells," Blood, vol. 111, no. 5, pp. 2631-2635, 2008.

[78] S. Sun, Z. Guo, X. Xiao et al., "Isolation of mouse marrow mesenchymal progenitors by a novel and reliable method," Stem Cells, vol. 21, no. 5, pp. 527-535, 2003.

[79] M. T. Harting, F. Jimenez, S. Pati, J. Baumgartner, and C. S. Cox, "Immunophenotype characterization of rat mesenchymal stromal cells," Cytotherapy, vol. 10, no. 3, pp. 243-253, 2008.

[80] S. Gu, C. Xing, J. Han, M. O. M. Tso, and J. Hong, "Differentiation of rabbit bone marrow mesenchymal stem cells into corneal epithelial cells in vivo and ex vivo," Molecular Vision, vol. 15, pp. 99-107, 2009.

[81] W. A. Noort, M. I. Oerlemans, H. Rozemuller et al., "Human versus porcine mesenchymal stromal cells: phenotype, differentiation potential, immunomodulation and cardiac improvement after transplantation," Journal of Cellular and Molecular Medicine. In press.
[82] R. Barzilay, O. Sadan, E. Melamed, and D. Offen, "Comparative characterization of bone marrow-derived mesenchymal stromal cells from four different rat strains," Cytotherapy, vol. 11, no. 4, pp. 435-442, 2009.

[83] W. S. Lee, Y. Suzuki, S. S. Graves et al., "Canine bone marrowderived mesenchymal stromal cells suppress alloreactive lymphocyte proliferation in vitro but fail to enhance engraftment in canine bone marrow transplantation," Biology of Blood and Marrow Transplantation, vol. 17, no. 4, pp. 465-475, 2011.

[84] A. C. W. Zannettino, S. Paton, S. Itescu, and S. Gronthos, "Comparative assessment of the osteoconductive properties of different biomaterials in vivo seeded with human or ovine mesenchymal stem/stromal cells," Tissue Engineering-Part A, vol. 16, no. 12, pp. 3579-3587, 2010.

[85] R. C. Mccarty, S. Gronthos, A. C. Zannettino, B. K. Foster, and C. J. Xian, "Characterisation and developmental potential of ovine bone marrow derived mesenchymal stem cells," Journal of Cellular Physiology, vol. 219, no. 2, pp. 324-333, 2009.

[86] A. Peister, J. A. Mellad, B. L. Larson, B. M. Hall, L. F. Gibson, and D. J. Prockop, "Adult stem cells from bone marrow (MSCs) isolated from different strains of inbred mice vary in surface epitopes, rates of proliferation, and differentiation potential," Blood, vol. 103, no. 5, pp. 1662-1668, 2004.

[87] S. M. Devine, A. M. Bartholomew, N. Mahmud et al., "Mesenchymal stem cells are capable of homing to the bone marrow of non-human primates following systemic infusion," Experimental Hematology, vol. 29, no. 2, pp. 244255, 2001.

[88] D. Bexell, S. Gunnarsson, A. Tormin et al., "Bone marrow multipotent mesenchymal stroma cells act as pericytelike migratory vehicles in experimental gliomas," Molecular Therapy, vol. 17, no. 1, pp. 183-190, 2009.

[89] E. J. Gang, D. Bosnakovski, C. A. Figueiredo, J. W. Visser, and R. C. R. Perlingeiro, "SSEA-4 identifies mesenchymal stem cells from bone marrow," Blood, vol. 109, no. 4, pp. 17431751, 2007.

[90] H. J. Buhring, S. Treml, F. Cerabona, P. De Zwart, L. Kanz, and M. Sobiesiak, "Phenotypic characterization of distinct human bone marrow-derived MSC subsets," in Hematopoietic Stem Cells, L. Kanz et al., Ed., pp. 124-134, Blackwell Scientific, Oxford, UK, 2009.

[91] E. A. Jones, S. E. Kinsey, A. English et al., "Isolation and characterization of bone marrow multipotential mesenchymal progenitor cells," Arthritis and Rheumatism, vol. 46, no. 12, pp. 3349-3360, 2002.

[92] E. A. Jones, A. English, S. E. Kinsey et al., "Optimization of a flow cytometry-based protocol for detection and phenotypic characterization of multipotent mesenchymal stromal cells from human bone marrow," Cytometry Part B, vol. 70, no. 6, pp. 391-399, 2006.

[93] O. Pierre-Louis, D. Clay, P. B. De La Grange et al., "Dual SP/ALDH functionalities refine the human hematopoietic $\mathrm{Lin}^{-} \mathrm{CD} 34^{+} \mathrm{CD} 38^{-}$stem/progenitor cell compartment," Stem Cells, vol. 27, no. 10, pp. 2552-2562, 2009.

[94] M. Vitacolonna, M. Schubert, N. Herbert et al., "Improved T and B cell recovery by the transfer of slowly dividing human hematopoietic stem cells," Leukemia Research, vol. 34, no. 5, pp. 622-630, 2010.

[95] S. Kuçi, Z. Kuçi, H. Kreyenberg et al., "CD271 antigen defines a subset of multipotent stromal cells with immunosuppressive and lymphohematopoietic engraftment-promoting properties," Haematologica, vol. 95, no. 4, pp. 651-659, 2010. 
[96] Z. Kuçi, S. Kuçi, S. Zircher et al., "Mesenchymal stromal cells derived from CD271(+) bone marrow mononuclear cells exert potent allosuppressive properties," Cytotherapy, vol. 13, no. 10, pp. 1193-1204, 2011.

[97] E. Jones and X. Yang, "Mesenchymal stem cells and bone regeneration: current status," Injury, vol. 42, no. 6, pp. 562568, 2011.

[98] A. Harichandan and H. J. Bühring, "Prospective isolation of human MSC," Best Practice and Research, vol. 24, no. 1, pp. 25-36, 2011.

[99] Z. Y. Zhang, S. H. Teoh, E. Y. Teo et al., "A comparison of bioreactors for culture of fetal mesenchymal stem cells for bone tissue engineering," Biomaterials, vol. 31, no. 33, pp. 8684-8695, 2010.

[100] P. Hernigou, A. Poignard, F. Beaujean, and H. Rouard, "Percutaneous autologous bone-marrow grafting for nonunions: influence of the number and concentration of progenitor cells," Journal of Bone and Joint Surgery-Series A, vol. 87, no. 7, pp. 1430-1437, 2005.

[101] J. E. Ip, Y. Wu, J. Huang, L. Zhang, R. E. Pratt, and V. J. Dzau, "Mesenchymal stem cells use integrin $\beta 1$ not CXC chemokine receptor 4 for myocardial migration and engraftment," Molecular Biology of the Cell, vol. 18, no. 8, pp. 2873-2882, 2007.

[102] A. A. Martins, A. Paiva, J. M. Morgado, A. Gomes, and M. L. Pais, "Quantification and immunophenotypic characterization of bone marrow and umbilical cord blood mesenchymal stem cells by multicolor flow cytometry," Transplantation Proceedings, vol. 41, no. 3, pp. 943-946, 2009.

[103] N. Bardin, F. George, M. Mutin et al., "S-Endo 1, a panendothelial monoclonal antibody recognizing a novel human endothelial antigen," Tissue Antigens, vol. 48, no. 5, pp. 531539, 1996.

[104] D. M. Lewinsohn, A. Nagler, N. Ginzton, P. Greenberg, and E. C. Butcher, "Hematopoietic progenitor cell expression of the H-CAM (CD44) homing-associated adhesion molecule," Blood, vol. 75, no. 3, pp. 589-595, 1990.

[105] M. E. Hemler, "VlA proteins in the integrin family: structures, functions, and their role on leukocytes," Annual Review of Immunology, vol. 8, pp. 365-400, 1990.

[106] S. T. Jalkanen, R. F. Bargatze, L. R. Herron, and E. C. Butcher, "A lymphoid cell surface glycoprotein involved in endothelial cell recognition and lymphocyte homing in man," European Journal of Immunology, vol. 16, no. 10, pp. 1195-1202, 1986.

[107] A. Ålgars, M. Karikoski, G. G. Yegutkin et al., "Different role of CD73 in leukocyte trafficking via blood and lymph vessels," Blood, vol. 117, no. 16, pp. 4387-4393, 2011.

[108] G. J. Wright, M. Jones, M. J. Puklavec, M. H. Brown, and A. N. Barclay, "The unusual distribution of the neuronal/lymphoid cell surface CD200 (OX2) glycoprotein is conserved in humans," Immunology, vol. 102, no. 2, pp. 173 179, 2001.

[109] K. F. Bradstock, E. J. Favaloro, and A. Kabral, "Myeloid progenitor surface antigen identified by monoclonal antibody," British Journal of Haematology, vol. 61, no. 1, pp. 11-20, 1985.

[110] S. T. Pals, F. Hogervorst, G. D. Keizer, T. Thepen, E. Horst, and C. C. Figdor, "Identification of a widely distributed 90-kDa glycoprotein that is homologous to the Hermes-1 human lymphocyte homing receptor," Journal of Immunology, vol. 143, no. 3, pp. 851-857, 1989.

[111] P. Lastres, C. Cabanas, T. Bellon et al., "Regulated expression on human macrophages of endoglin, an Arg-Gly-Aspcontaining surface antigen," European Journal of Immunology, vol. 22, no. 2, pp. 393-397, 1992.
[112] B. Nieswandt, D. Varga-Szabo, and M. Elvers, "Integrins in platelet activation," Journal of Thrombosis and Haemostasis, vol. 7, supplement 1, pp. 206-209, 2009.

[113] L. L. W. Cooling, D. Zhang, and T. A. W. Koerner, "Human platelets express gangliosides with LKE activity and $\mathrm{ABH}$ blood group activity," Transfusion, vol. 41, no. 4, pp. 504-516, 2001.

[114] P. Tippett, P. W. Andrews, and B. B. Knowles, "Red cell antigens P (globoside) and Luke: identification by monoclonal antibodies defining the murine stage-specific embryonic antigens -3 and -4 (SSEA-3 and SSEA-4)," Vox Sanguinis, vol. 51, no. 1, pp. 53-56, 1986.

[115] E. J. Favaloro, “CD-13 ('gp 150'; aminopeptidase-N): coexpression on endothelial and haemopoietic cells with conservation of functional activity," Immunology and Cell Biology, vol. 69, part 4, pp. 253-260, 1991.

[116] G. Conforti, C. Dominguez-Jimenez, A. Zanetti et al., "Human endothelial cells express integrin receptors on the luminal aspect of their membrane," Blood, vol. 80, no. 2, pp. 437-446, 1992.

[117] A. Gougos and M. Letarte, "Identification of a human endothelial cell antigen with monoclonal antibody 44G4 produced against a pre-B leukemic cell line," Journal of Immunology, vol. 141, no. 6, pp. 1925-1933, 1988.

[118] L. Osborn, C. Hession, R. Tizard et al., "Direct expression cloning of vascular cell adhesion molecule 1, a cytokineinduced endothelial protein that binds to lymphocytes," Cell, vol. 59, no. 6, pp. 1203-1211, 1989.

[119] G. Lin, G. Liu, L. Banie et al., "Tissue distribution of mesenchymal stem cell marker Stro-1," Stem Cells and Development, vol. 20, no. 10, pp. 1747-1752, 2011.

[120] K. Stewart, S. Walsh, J. Screen et al., "Further characterization of cells expressing STRO-1 in cultures of adult human bone marrow stromal cells," Journal of Bone Mineral Research, vol. 14, no. 8, pp. 1345-1356, 1999.

[121] D. Alexander, F. Schäfer, A. Munz et al., "LNGFR induction during Osteogenesis of human jaw periosteum-derived cells," Cellular Physiology and Biochemistry, vol. 24, no. 3-4, pp. 283-290, 2009.

[122] Y. Mikami, Y. Ishii, N. Watanabe et al., "CD271/p75NTR inhibits the differentiation of mesenchymal stem cells into osteogenic, adipogenic, chondrogenic, and myogenic lineages," Stem Cells and Development, vol. 20, no. 5, pp. 901913, 2011.

[123] G. Civenni, A. Walter, N. Kobert et al., "Human CD271positive melanoma stem cells associated with metastasis establish tumor heterogeneity and long-term growth," Cancer Research, vol. 71, no. 8, pp. 3098-3109, 2011.

[124] K. Inoue, N. Aoi, T. Sato et al., "Differential expression of stem-cell-associated markers in human hair follicle epithelial cells," Laboratory Investigation, vol. 89, no. 8, pp. 844-856, 2009.

[125] M. Sobiesiak, K. Sivasubramaniyan, C. Hermann et al., "The mesenchymal stem cell antigen MSCA-1 is identical to tissue non-specific alkaline phosphatase," Stem Cells and Development, vol. 19, no. 5, pp. 669-677, 2010.

[126] O. Nosjean, I. Koyama, M. Goseki, B. Roux, and T. Komoda, "Human tissue non-specific alkaline phosphatases: sugarmoiety-induced enzymic and antigenic modulations and genetic aspects," Biochemical Journal, vol. 321, part 2, pp. 297-303, 1997.

[127] K. N. Fedde, L. Blair, J. Silverstein et al., "Alkaline phosphatase knock-out mice recapitulate the metabolic and skeletal defects of infantile hypophosphatasia," Journal of 
Bone and Mineral Research, vol. 14, no. 12, pp. 2015-2026, 1999.

[128] S. Gronthos, S. Fitter, P. Diamond, P. J. Simmons, S. Itescu, and A. C. W. Zannettino, "A novel monoclonal antibody (STRO-3) identifies an isoform of tissue nonspecific alkaline phosphatase expressed by multipotent bone marrow stromal stem cells," Stem Cells and Development, vol. 16, no. 6, pp. 953-963, 2007.

[129] R. Cuthbert, S. A. Boxall, H. B. Tan, P. V. Giannoudis, D. McGonagle, and E. Jones, "Single-platform quality control assay to quantify multipotential stromal cells in bone marrow aspirates prior to bulk manufacture or direct therapeutic use," Cytotherapy, vol. 14, no. 4, pp. 431-440, 2012.

[130] R. Veyrat-Masson, N. Boiret-Dupré, C. Rapatel et al., "Mesenchymal content of fresh bone marrow: a proposed quality control method for cell therapy," British Journal of Haematology, vol. 139, no. 2, pp. 312-320, 2007.

[131] B. Sacchetti, A. Funari, S. Michienzi et al., "Self-renewing osteoprogenitors in bone marrow sinusoids can organize a hematopoietic microenvironment," Cell, vol. 131, no. 2, pp. 324-336, 2007.

[132] M. Crisan, S. Yap, L. Casteilla et al., "A perivascular origin for mesenchymal stem cells in multiple human organs," Cell Stem Cell, vol. 3, no. 3, pp. 301-313, 2008.

[133] M. W. Maijenburg, M. Kleijer, K. Vermeul et al., "The composition of the mesenchymal stromal cell compartment in human bone marrow changes during development and aging," Haematologica, vol. 97, no. 2, pp. 179-183, 2011.

[134] N. Sato, L. Meijer, L. Skaltsounis, P. Greengard, and A. H. Brivanlou, "Maintenance of pluripotency in human and mouse embryonic stem cells through activation of Wnt signaling by a pharmacological GSK-3-specific inhibitor," Nature Medicine, vol. 10, no. 1, pp. 55-63, 2004.

[135] N. Tremain, J. Korkko, D. Ibberson, G. C. Kopen, C. DiGirolamo, and D. G. Phinney, "MicroSAGE analysis of 2,353 expressed genes in a single cell-derived colony of undifferentiated human mesenchymal stem cells reveals mRNAS of multiple cell lineages," Stem Cells, vol. 19, no. 5, pp. 408-418, 2001.

[136] S. M. Churchman, F. Ponchel, S. A. Boxall et al., "Multipotential Stromal Cells (MSCs) have a transcript profile indicative of multiple fates with prominent Osteogenic and Wnt pathway signalling activity," Arthritis and Rheumatism. In press.

[137] A. Kortesidis, A. Zannettino, S. Isenmann, S. Shi, T. Lapidot, and S. Gronthos, "Stromal-derived factor-1 promotes the growth, survival, and development of human bone marrow stromal stem cells," Blood, vol. 105, no. 10, pp. 3793-3801, 2005.

[138] N. Quirici, C. Scavullo, L. De Girolamo et al., "Anti-L-NGFR and -CD34 monoclonal antibodies identify multipotent mesenchymal stem cells in human adipose tissue," Stem Cells and Development, vol. 19, no. 6, pp. 915-925, 2010.

[139] M. C. Arufe, A. De La Fuente, I. Fuentes, F. J. De Toro, and F. J. Blanco, "Chondrogenic potential of subpopulations of cells expressing mesenchymal stem cell markers derived from human synovial membranes," Journal of Cellular Biochemistry, vol. 111, no. 4, pp. 834-845, 2010.

[140] T. B. Kurth, F. Dell'Accio, V. Crouch, A. Augello, P. T. Sharpe, and C. De Bari, "Functional mesenchymal stem cell niches in adult mouse knee joint synovium in vivo," Arthritis and Rheumatism, vol. 63, no. 5, pp. 1289-1300, 2011.

[141] V. L. Battula, P. M. Bareiss, S. Treml et al., "Human placenta and bone marrow derived MSC cultured in serum-free,
b-FGF-containing medium express cell surface frizzled-9 and SSEA-4 and give rise to multilineage differentiation," Differentiation, vol. 75, no. 4, pp. 279-291, 2007. 

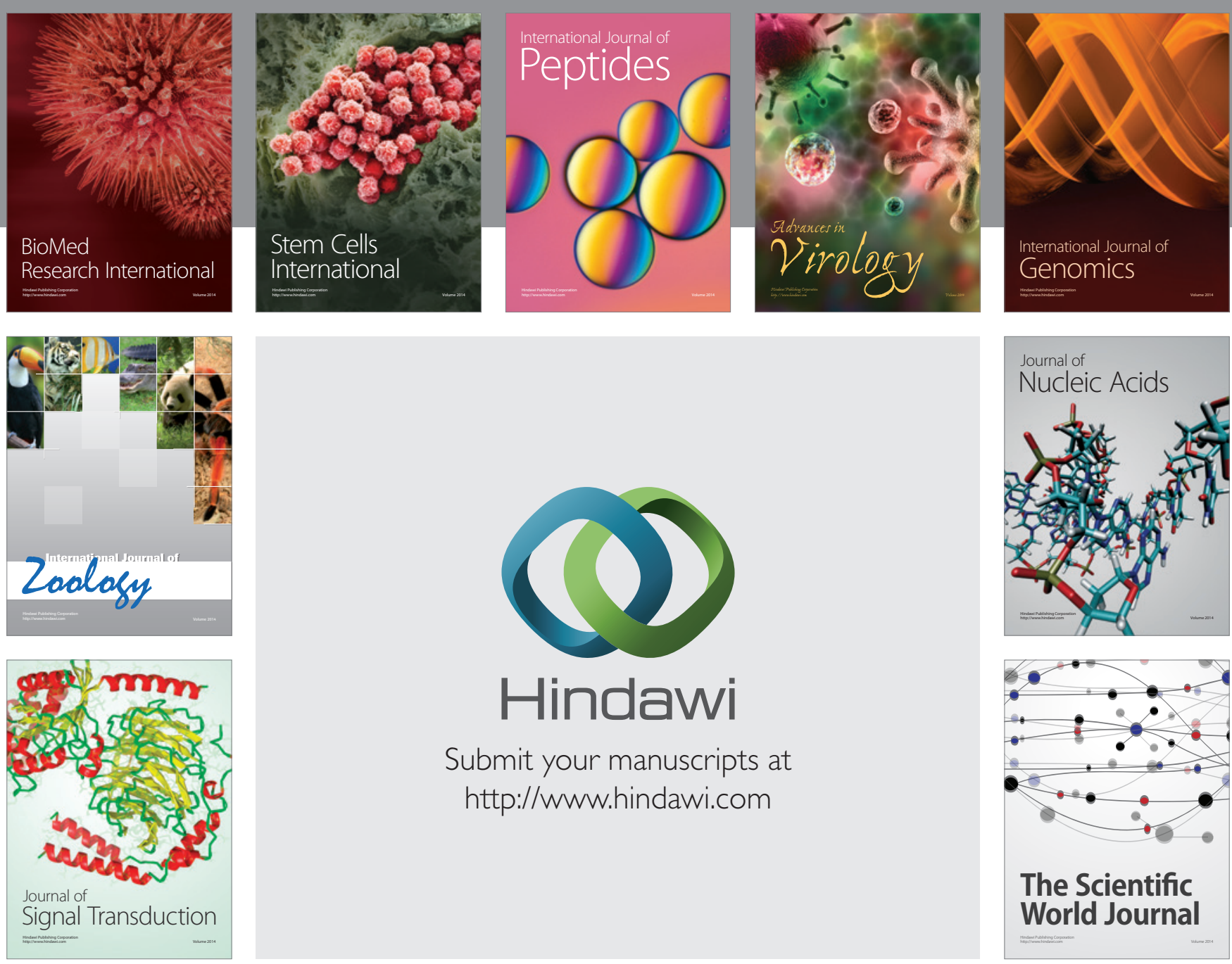

Submit your manuscripts at

http://www.hindawi.com
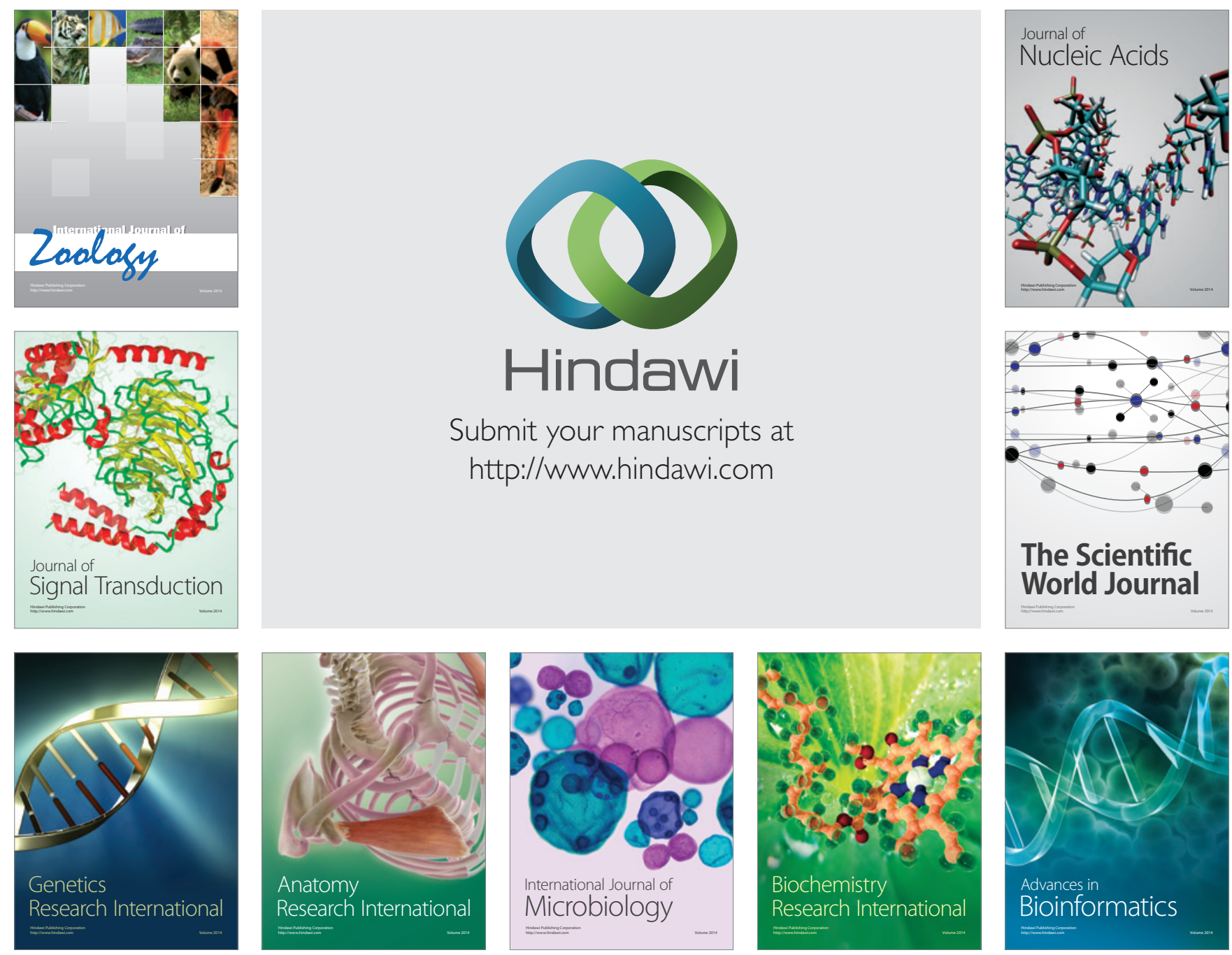

The Scientific World Journal
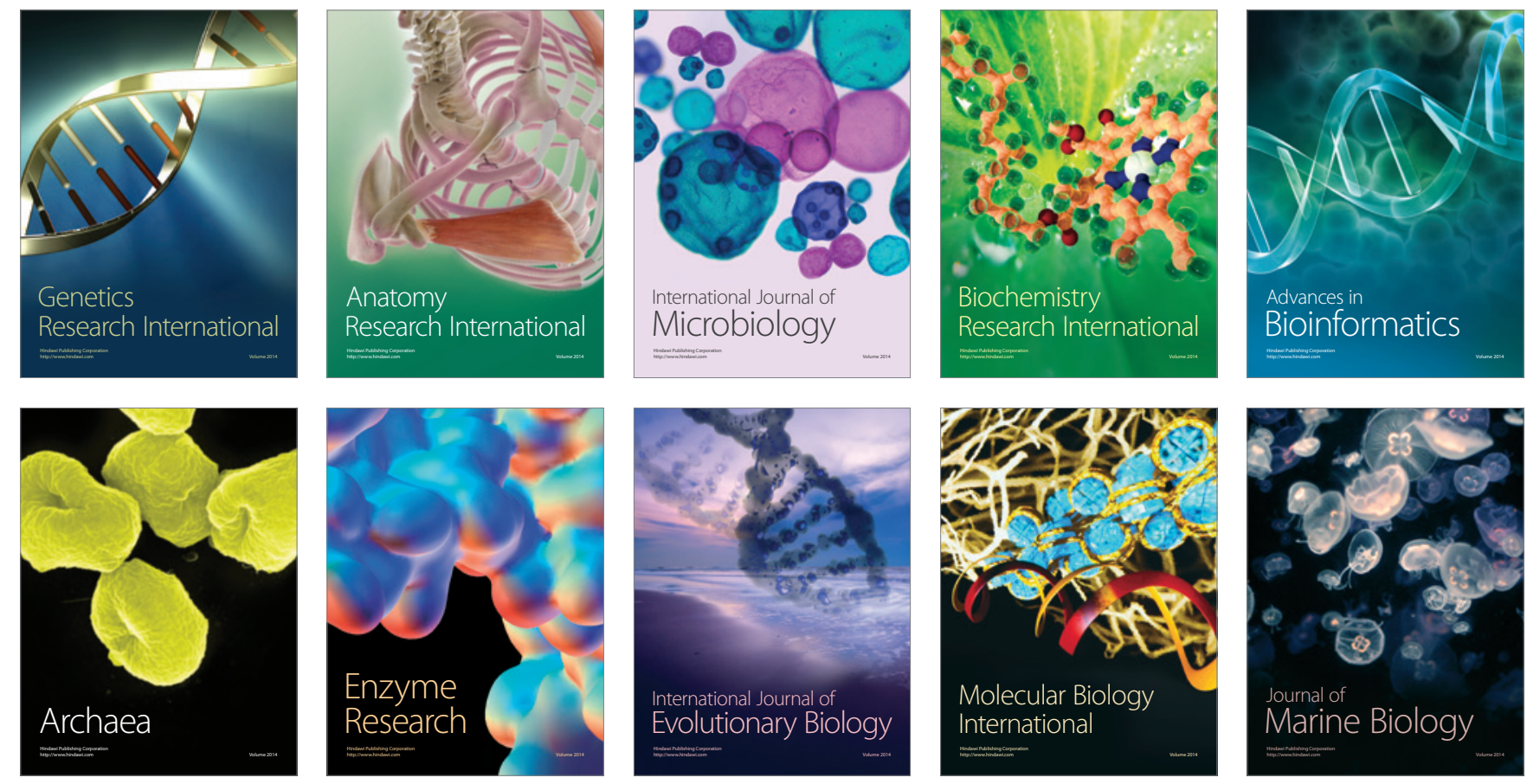